\title{
KEMAMPUAN MENGIDENTIFIKASI STRUKTUR DAN UNSUR KEBAHASAAN OLEH SISWA KELAS VIII SMP NEGERI 12 MEDAN TAHUNPEMBELAJARAN 2017/2018
}

\author{
Oleh \\ Nova Yanti Siregar (nOphayanti@yahoo.com) \\ Dra. Rosmaini, M.Pd. (rosmainifadil@yahoo.com)
}

\begin{abstract}
ABSTRAK
Penelitian ini menggunakan sampel yaitu sebanyak 81 siswa kelas VIII.Adapun metode yang digunakan dalam penelitian ini adalah metode deskriptif, peneliti tidak melakukan kontrol manipulasi variabel penelitian.Instrumen yang digunakan dalam penelitian ini adalah tes untuk mengetahui kemampuan mengidentifikasi teks ulasan berdasarkan struktur dan unsur kebahasaan oleh siswa kelas VIII SMP Negeri 12 Medan tahun pembelajaran 2017/2018.

Ditinjau dari tabel uji kategori, terdapat $2(2,5 \%)$ siswa tergolong dalam kategori baik dengan rentang nilai 70-84, 41 $(50,6 \%)$ siswa tergolong dalam kategori cukup dengan rentang nilai 60-69, 30 (37\%) siswa tergolong dalam kategori kurang dengan rentang nilai 50-59, dan $8(9,9 \%)$ siswa tergolong dalam kategori sangat kurang dengan rentang nilai 0-49. Berdasarkan tabel frekuensi dan kategori penilaian, maka dapat disimpulkan bahwa kemampuan mengidentifikasi teks ulasan berdasarkan struktur dan unsur kebahasaan masih tergolong dalam kategori cukup.Hal tersebut disebabkan karena siswa masih belum mampu mengidentifikasi seluruh unsur kebahasaan yang ada pada teks, serta masih melakukan kesalahan dalam mengidentifikasi strukturteks ulasan.Hal ini yang terjadi pada siswa kelas VIII SMP Negeri 12 Medan.
\end{abstract}

Kata kunci: Struktur, unsur kebahasaan, teks ulasan.

\section{PENDAHULUAN}

Kurikulum2013memuatKompetensiInti,KompetensiDasar,danmateripemb elajaran.Pengembangankurikulum2013merupakanstrategiuntukmeningkatkanpenc apaianpendidikan.TerkaitdenganimplementasiKurikulum2013,pembelajaranbahas aIndonesiamengalamipembaharuan.SalahsatuparadigmabarupembelajaranbahasaI ndonesiadalamKurikulum2013adalahpembelajaranbahasaIndonesiaberbasisteks. 
Salah satu teks yang dipelajari oleh siswa SMP kelas VIII adalah teks ulasan. Dalam buku guru bahasa Indonesia dijelaskan bahwa teks ulasan adalah sebuah teks yang dihasilkan dari sebuah analisis terhadap berbagai hal. Analisis itu bisa berbentuk buku, novel, berita, laporan, atau dongeng.Teks tersebut memberikan tanggapan atau analisis yang berhubungan dengan latar, waktu, tempat, serta karakter yang ada di dalam teks. Pada dasarnya, teks ulasan adalah tinjauan atau ringkasan buku atau yang lain untuk koran atau penerbitan. Teks ulasan (review) merupakan suatu teks yang memiliki tujuan sosial untuk menilai daya tarik dari suatu karya (Mahsun, 2014: 21).Pada pembelajaran teks ulasan di SMP kelas VIII, siswa menilai berbagai jenis karya sastra, baik karya sastra dalam bentuk prosa, puisi, maupun drama.Hasil penilaian terhadap suatu karya sastra tersebut dikomunikasikan kepada pembaca.Untuk memahami teks ulasan, siswa harus mengetahui struktur teks ulasan serta unsur-unsur kebahasaan yang mendukung teks tersebut.

Teks ulasan dibangun oleh isi dan struktur, khususnya unsur kebahasaan yang membedakan teks ulasan dengan teks lainnya.Apabila dikaitkan dengan aspek penguasaan struktur dan unsur kebahasaan, siswa diharapkan mampu memahami dan mengidentifikasi terlebih dahulu struktur dan unsur kebahasaan sebagai wujud lahiriah atau bentuk fisik dari teks ulasan.Di samping itu, dalam hal unsur kebahasaan, siswa dituntut sering membaca teks ulasan, menyimak, atau menonton drama. Dengan demikian, siswa akan terlatih dalam menentukan stuktur dan unsur kebahasaan teks ulasan sekaligus terampil menulis, khususnya menulis teks ulasan. Artinya, hasil pembelajaran yang menjadi indikator dapat berjalan dengan baik.

Teks ulasan merupakan salah satu materi ajar yang dapat meningkatkan keterampilan menulis siswa.Dengan mengulas suatu film maupun drama, kita diharuskan untuk bersikap lebih kritis. Tetapi sebelum menulis teks ulasan, siswa harus mampu memahami struktur dan unsur kebahasaan sebuah teks yang dipelajari agar ketika menulis siswa dapat lebih paham dalam menuangkan ide atau gagasan dalam pikirannya.Senada dengan penelitian Fitriani (2016: 7) yang berjudul "Peningkatan Keterampilan Menulis Teks Ulasan Film Pendek Dengan 
Strategi Think Talk Write (TTW) Pada Siswa Kelas XI IPS1 SMAN 1 Sewon Bantul DIY”, dikatakan bahwa siswa masih kurang mampu menuangkan hasil pemikirannya ke dalam bentuk tulisan teks ulasan, hal ini dikarenakan siswa masih kurang memahami struktur dan ciri bahasa teks ulasan. Oleh karena pentingnya memahami struktur dan unsur kebahasaan teks ulasan, peneliti tertarik untuk meneliti kemampuan mengidentifikasi teks ulasan berdasarkan struktur dan unsur kebahasaan oleh siswa kelas VIII SMP Negeri 12 Medan.Penelitian ini bertujuan untuk mengukur kemampuan siswa dalam mengindentifikasi struktur dan unsur kebahasaan teks ulasan.

Teks ulasan dihasilkan dari sebuah analisis terhadap berbagai hal.Analisis itu bisa berbentuk buku, novel, berita, laporan, dongeng.Teks ini memberikan tanggapan atau analisis yang berhubungan dengan latar, waktu, tempat, serta karakter dalam teks.Untuk memahami teks ulasan, siswa harus mengetahui struktur serta unsur kebahasaan yang mendukung teks (Kemendikbud, 2014: 114).Setiap teks pasti memiliki strukturnya masing-masing, begitu pula dengan struktur teks ulasan. Struktur merupakan cara sesuatu, disusun atau dibangun. Teks ulasan memiliki struktur tersendiri yang membedakannya dengan teks lain. Teks ulasan merupakan salah satu teks yang bersifat argumentatif.Kemendikbud (2014: 122) membagi struktur teks ulasan menjadi empat bagian.Diawali oleh orientasi (orientation), tafsiran isi (interpretative recount), evaluasi (evaluation).Dibagian akhir teks ditutup dengan rangkuman (evaluative summation). Bagian orientasi berisi tentang gambaran umum sebuah karya atau benda yang akan diulas, tafsiran isi berisi tentang gambaran yang disampaikan secara lebih rinci, tentang kualitas serta keunikan dari karya yang sedang diulas Bagian evaluasi berisi tentang pandangan dari pengulas mengenai hasil karya yang diulas. Hal ini dilakukan setelah melakukan tafsiran yang cukup terhadap hasil karya tersebut. Pada bagian ini penulis akan menyebutkan bagian yang bernilai (kelebihan) atau bagian yang kurang (kekurangan) dari suatu karya. Bagian rangkuman berisi ulasan akhir yang berisi simpulan karya tersebut dengan mengemukakan kembali keseluruhan opini pada teks. 
Unsur kebahasaan merupakan salah satu syarat pengetahuan yang harus dikuasai oleh siswa agar dapat menghasilkan tulisan teks ulasan dengan baik dan benar. Unsur kebahasaan tersebut disesuaikan dengan silabus kelas VIII SMP pada kurikulum 2013 serta menghubungkannya dengan materi pelajaran yang ada didalam buku siswa Bahasa Indonesia. Unsur kebahasaan menurut Kemendikbud (2014: 124-126) adalah sebagai berikut. (a) Menggunakan kata sifat sikap, (b) Menggunakan kata benda, (c) Menggunakan kata kerja, (d) Menggunakan kata metafora, (e) Menggunakan kata rujukan, (f) Menggunakan kalimat kompleks.

\section{METODE PENELITIAN}

Metode penelitian adalah suatu cara dalam proses pemecahan masalah dengan mengumpulkan dan menganalisis data untuk mencapai tujuan yang diinginkan. Metode adalah cara atau langkah yang telah diatur dengan pemikiran yang baik untuk mencapai suatu maksud. Metode penelitian ditujukan untuk mencapai sasaran penelitian. Menurut Arikunto (2013:160) "Metode penelitian adalah cara yang digunakan oleh peneliti dalam mengumpulkan data penelitiannya."

Dalam penelitian ini penulis menggunakan metode deskriptif, yaitu suatu metode yang berusaha menggambarkan situasi atau gejala yang terjadi dalam keadaan nyata. Dalam penelitian deskriptif, peneliti tidak melakukan manipulasi atau memberi perlakuan-perlakuan tertentu terhadap variabel, tetapi semua kegiatan, keadaan, kejadian, aspek komponen, atau variabel berjalan apa adanya. Penemuan makna adalah fokus dari keseluruhan proses yang akan dilakukan.

\section{HASIL PENELITIAN DAN PEMBAHASAN}

\section{Hasil Penelitian}

\section{Kemampuan Mengidentifikasi Teks Ulasan Berdasarkan Struktur dan Unsur Kebahasaan Oleh Siswa Kelas VIII SMP Negeri 12 Medan Tahun Pembelajaran 2017/2018}

Nilai rata-rata kemampuan mengidentifikasi teks ulasan berdasarkan struktur dan unsur kebahasaanoleh siswa kelas VIII SMP Negeri 12 Medan tahun pembelajaran 2017/2018 adalah 58,33.Berdasarkan perhitungan di atas, maka 
diketahui nilai rata-rata kemampuan mengidentifikasi teks ulasan berdasarkan struktur oleh siswa kelas VIII SMP Negeri 12 Medan tahun pembelajaran 2017/2018struktur berada pada kategori kurang.

\section{Kemampuan Mengidentifikasi Teks Ulasan Berdasarkan Struktur Oleh Siswa Kelas VIII SMP Negeri 12 Medan Tahun Pembelajaran 2017/2018}

Nilai rata-rata kemampuanmengidentifikasi teks ulasan berdasarkan struktur oleh siswa kelas VIII SMP Negeri 12 Medan tahun pembelajaran 2017/2018adalah 79,17.Berdasarkan perhitungan di atas, maka diketahui nilai rata-rata kemampuan mengidentifikasi teks ulasan berdasarkan struktur oleh siswa kelas VIII SMP Negeri 12 Medan tahun pembelajaran 2017/2018struktur berada pada kategori baik.

\section{Kemampuan Mengidentifikasi Teks Ulasan Berdasarkan Unsur Kebahasaan Oleh Siswa Kelas VIII SMP Negeri 12 Medan Tahun Pembelajaran 2017/2018}

Nilai rata-rata kemampuan mengidentifikasi teks ulasan berdasarkan unsur kebahasaanoleh siswa kelas VIII SMP Negeri 12 Medan tahun pembelajaran 2017/2018adalah 44,44.Berdasarkan perhitungan di atas, maka diketahui nilai rata-rata kemampuan mengidentifikasi teks ulasan berdasarkan unsur kebahasaanoleh siswa kelas VIII SMP Negeri 12 Medan tahun pembelajaran 2017/2018 berada pada kategori sangat kurang.

\section{Pembahasan Hasil Penelitian}

Kemampuan mengidentifikasi teks ulasan berdasarkan struktur dan unsur kebahasaan dikategorikan kurang. Hal tersebut didasari karena secara keseluruhan, siswa kurang mampu mengidentifikasi teks ulasan berdasarkan struktur dan unsur kebahasaan dan hanya memperoleh nilai rata-rata hanya 58,33. Nilai tertinggi pada kemampuan mengidentifikasi teks ulasan berdasarkan struktur dan unsur kebahasaan adalah 70 dan nilai terendah adalah 40 . 
Ditinjau dari tabel persentase, diketahui jumlah terbanyak sekitar 41 orang siswa berada pada kategori cukup, yang artinya siswa secara keseluruhan cukup mampu mengidentifikasi teks ulasan berdasarkan struktur dan unsur kebahasaan.Dalam hal ini siswa masih kurang teliti saat mengerjakan tes, sehingga siswa tidak memiliki cukup waktu mengidentifikasi seluruh struktur dan unsur kebahasaan yang ada pada teks tersebut. Selain itu, kondisi di dalam kelas juga masih tergolong kurang kondusif, dikarenakan siswa lain yang banyak bertanya karena kurang mengerti dan disebabkan oleh kondisi ruangan kelas yang terbuka sehingga menyebabkan siswa kurang dapat berkonsentrasi.

\section{Kemampuan Mengidentifikasi Teks Ulasan Berdasarkan Struktur Oleh Siswa Kelas VIII SMP Negeri 12 Medan Tahun Pembelajaran 2017/2018}

Setelah melakukan penelitian, pengumpulan data, pengolahan data, dan penganalisisan data, dapat diketahui bahwa kemampuan mengidentifikasi teks ulasan berdasarkan struktur dikategorikan baik. Dalam penelitian ini, penilaian kategori dilakukan sesuai dengan yang dikemukakan oleh Sudijono (2013: 93), dengan demikian kemampuan mengidentifikasi teks ulasan berdasarkan struktur termasuk dalam kategori baik dengan rentang nilai 70-84 atau dapat dilihat dari pencapaian nilai rata-rata siswa yaitu 79,17 .

Tabel 1.1 Jumlah Siswa Berdasarkan Skor dalam Mengidentifikasi Teks Ulasan
Berdasarkan Struktur

\begin{tabular}{|c|c|c|c|c|}
\hline \multirow{2}{*}{ Skor } & \multicolumn{4}{|c|}{ Jumlah Siswa } \\
\cline { 2 - 5 } & Orientasi & Tafsiran isi & Evaluasi & Rangkuman \\
\hline 4 & $51(63 \%)$ & $24(30 \%)$ & $19(23,4 \%)$ & $53(65,43)$ \\
\hline 3 & $16(20 \%)$ & $31(38 \%)$ & $38(47 \%)$ & $11(13,6 \%)$ \\
\hline 2 & $14(17 \%)$ & $25(31 \%)$ & $18(22,2 \%)$ & $14(17,28)$ \\
\hline 1 & $0(\%)$ & $1(1 \%)$ & $6(7,4 \%)$ & $3(3,7 \%)$ \\
\hline Jumlah & $81(100 \%)$ & $81(100 \%)$ & $81(100 \%)$ & $81(100 \%)$ \\
\hline
\end{tabular}

Dalam menentukan struktur orientasi, terdapat sebanyak 50 dari 81 atau sekitar $62 \%$ siswa mendapat perolehan skor maksimal yaitu 4, pada bagian 
tafsiran isi terdapat sebanyak 31 dari 81 atau sekitar 38,3\% siswa mendapat perolehan skor 2 dan hanya sekitar 23 siswa yang mendapat perolehan skor maksimal yaitu 4, pada bagian evaluasi terdapat sebanyak 38 dari 81 atau sekitar 47\% siswa mendapat perolehan skor 2 dan hanya sekitar 19 siswa yang mendapat perolehan skor maksimal yaitu 4, dan pada bagian rangkuman terdapat sebanyak 53 dari 81 atau sekitar 65,4\% siswa mendapat perolehan skor maksimal yaitu 4 .

Sebagai kesimpulan, siswa paling banyak menjawab dengan tepat yaitu pada struktur bagian rangkuman.Siswa lebih memahami struktur rangkuman dibandingkan struktur pada bagian lainnya, terutama pada bagian tafsiran isi dan evaluasi.Masalah yang ditemukan adalah, kurangnya pemahaman dan pelatihan atau praktik siswa dalam mengidentifikasi struktur teks ulasan terutama bagian tafsiran isi dan evaluasi.

\section{Kemampuan Mengidentifikasi Teks Ulasan Berdasarkan Unsur Kebahasaan Oleh Siswa Kelas VIII SMP Negeri 12 Medan Tahun Pembelajaran 2017/2018}

Setelah melakukan penelitian, pengumpulan data, pengolahan data, dan penganalisisan data, dapat diketahui bahwa kemampuan mengidentifikasi teks ulasan berdasarkan struktur dikategorikan sangat kurang. Dalam penelitian ini, penilaian kategori dilakukan sesuai dengan yang dikemukakan oleh Sudijono (2013: 93), dengan demikian kemampuan mengidentifikasi teks ulasan berdasarkan struktur termasuk dalam kategori baik dengan rentang nilai 0-49 atau dapat dilihat dari pencapaian nilai rata-rata siswa yaitu 44,44.

Tabel 1.2

Jumlah Siswa Berdasarkan Skor dalam Mengidentifikasi Teks Ulasan Berdasarkan Struktur

\begin{tabular}{|c|c|c|c|c|c|c|}
\hline \multirow[t]{2}{*}{ Skor } & \multicolumn{6}{|c|}{ Jumlah Siswa } \\
\hline & $\begin{array}{c}\text { Kata Sifat } \\
\text { Sikap }\end{array}$ & $\begin{array}{c}\text { Kata } \\
\text { Benda }\end{array}$ & Kata Kerja & $\begin{array}{c}\text { Kata } \\
\text { Metafora }\end{array}$ & $\begin{array}{c}\text { Kata } \\
\text { Rujukan }\end{array}$ & $\begin{array}{l}\text { Kalimat } \\
\text { Kompleks }\end{array}$ \\
\hline 4 & - & - & - & - & $1(1,23 \%)$ & $1(1,23 \%)$ \\
\hline 3 & $4(4,9 \%)$ & - & $2(2,5 \%)$ & $3(3,7 \%)$ & $12(14,82 \%)$ & $9(11,1 \%)$ \\
\hline 2 & $74(91,4 \%)$ & $76(94 \%)$ & $67(82,7 \%)$ & $54(66,7 \%)$ & $30(37,04 \%)$ & $12(14,8 \%)$ \\
\hline 1 & $3(3,7 \%)$ & $5(6 \%)$ & $12(14,8 \%)$ & $24(29,6 \%)$ & $38(46,91 \%)$ & $59(72,9 \%)$ \\
\hline Jumlah & $81(100 \%)$ & $81(100 \%)$ & $81(100 \%)$ & $81(100 \%)$ & $81(100 \%)$ & $81(100 \%)$ \\
\hline
\end{tabular}


Siswa dikatakan sangat kurang dalam segi unsur kebahasaan disebabkan siswa kurang mampu mengidentifikasi seluruh unsur kebahasaan teks ulasan.Hal ini didasari karena dalam mengidentifikasi teks ulasan siswa belum terbiasa menemukan unsur kebahasaan dalam suat teks seperti kata sifat sikap, kata benda, kata kerja, kata metafora, kata rujukan, dan kalimat kompleks.

\section{PENUTUP}

Berdasarkan hasil penelitian yang telah diuraikan pada pembahasan, maka diperoleh simpulan, Kemampuan mengidentifikasi teks ulasan berdasarkan struktur oleh siswa kelas VIII SMP Negeri 12 Medan tahun pembelajaran 2017/2018 berada pada kategori baik. Hal tersebut dilihat dari nilai rata-rata siswa mengidentifikasi struktur teks ulasan yaitu 79,17.

Kemampuan mengidentifikasi teks ulasan berdasarkan unsur kebahasaan berada pada kategori kurang. Hal tersebut dilihat dari nilai rata-rata siswa mengidentifikasi unsur kebahasaan teks ulasan yaitu 44,44.

\section{DAFTAR PUSTAKA}

Alfianika, Ninit. 2016. Metode Penelitian Pengajaran Bahasa Indonesia. Yogyakarta: Deepublish

Arikunto, Suharsimi. 2014. Prosedur Penelitian: Suatu Pendekatan Praktik. Jakarta: Rineka Cipta

Arnita. 2013. Pengantar Statistika. Bandung: Citapustaka Media Perintis

Depdikbud.2005. Kamus Besar Bahasa Indonesia. Jakarta: Balai pustaka

Farida, Siti Isnatun, Umi. 2013. Mahir Berbahasa Indonesia. Bogor: Yudistira

Fitriani, 2016.Peningkatan Keterampilan Menulis Teks Ulasan Film Pendek Dengan Strategi Think Talk Write (TTW) Pada Siswa Kelas XI IPS1 SMA Negeri 1 Sewon Bantul DIY. Skripsi: Universitas Negeri Yogyakarta 
Kemendikbud. 2014. Buku Guru Bahasa Indonesia: Wahana Pengetahuan. Jakarta: Kementrian Pendidikan dan Kebudayaan 2014. Buku Siswa Bahasa Indonesia: Wahana Pengetahuan. Jakarta: Kementrian Pendidikan dan Kebudayaan

Kosasih. 2014. Jenis-Jenis Teks. Bandung: Yrama Widya

Mahsun.2014. Teks Dalam Pembelajaran Bahasa Indonesia.Kurikulum 2013. Jakarta: PT RajaGrafindo Persada

Sugiyono. 2016. Metode Penelitian Pendidikan; Pendekatan Kuantitatif, Kualitatif, dan $R \& D$. Bandung: Alfabeta

Sudijono, Anas. 2013. Pengantar Statistik Pendidikan. Jakarta: Rajawali Pers 